\title{
A rural intervention in the urban context: an urban-poor neighbourhood agricultural project in Küçük Armutlu, Istanbul
}

\author{
S. Doyduk ${ }^{1}$, B. Orbey ${ }^{2} \&$ N. Gurel ${ }^{2}$ \\ ${ }^{1}$ Deparment of Architecture, Sakarya University, Turkey \\ ${ }^{2}$ Deparment of Architecture, Dogus University, Turkey
}

\begin{abstract}
Activities and locations inhabited create distinctions between rural and urban living. Today some cases start to deconstruct these distinctions. The case study of Küçük Armutlu, which this paper will delve into, is located in the heart of Istanbul with strong ties to urban daily life. This paper will investigate how a recent agricultural regeneration project, Community Garden, within the urban context acts as a tool to maintain a sustainable community with a rural character.

An unofficial civic organization called "People's Engineers and Architects" had initiated a dynamic sustainable project called Community Garden Project. This project aims to fulfill the low-income resident's vital vegetation needs. However, this is not the sole intention of the garden. It stands out as a place of struggle and solidarity for a sustainable community where the neighbourhood is under the threat of urban transformation attempts by the government.

The issue is investigated through observations and in depth interviews with the habitants of Küçük Armutlu, people taking part in the garden project and members of People's Engineers and Architects group as well as People's Committee.

Keywords: sustainable community, community garden, urban-rural boundaries, solidarity stance, Kü̧̈ük Armutlu, Istanbul.
\end{abstract}

\section{Introduction}

The world became increasingly urbanized. Therefore, the boundaries between rural and urban are deconstructed. Urban agriculture practices blur this urbanrural distinction by relocating traditional 'rural' practices into urban life. Küçük 
Armutlu (K. Armutlu) is a unique neighbourhood as it spends an effort and achieves to preserve rural traditions in an urban setting through its relation to green, social organization and social interaction. K. Armutlu differs from other neighbourhoods by means of organization through a revolutionist group standing up for their rights to dwell, against the attempts of the government to gain economic value over the urban lots of K. Armutlu through urban transformation. The control mechanism established through the appearance of the neighbourhood is what makes sure the neighbourhood keeps its rural character in an urban setting. Preservation of private gardens as well as establishment of a Community Garden is a tactical move against the government. The interactive nature of the Community Garden is a representative of the neighbourhood culture achieved. The aim of this garden is not sustainable ecology but a stronger solidarity stance in the neighbourhood for a sustainable community.

\section{Blurred boundaries between urban and rural character}

25 years ago, half the world's workforce was farmers. However, in recent years the world's urban population has just passed $50 \%$, implying this is a permanent trend [1]. The world is increasingly urbanized, almost half of the world's populations living in the cities. Turkey has also witnessed rapid industrialization and urbanization in the second half of the 20th century; through modernization of agriculture as rural to urban population movements emerged. In 1950-1980s, the power of labour has urbanized [2].

The daily life commons defined as urban and rural living appears from the locations and daily activities. Rural and urban areas are usually defined by a certain size and population; agriculture is considered to be the main practice of rural populations. Urban populations are assumed to engage mainly in industry and service [3]. Through urbanization, the boundaries between rural and urban are deconstructed. Urban agriculture practices blur this urban-rural distinction by relocating traditional "rural" practices into urban life. This paper's focus is the case of K. Armutlu neighbourhood where these urban - rural boundaries are blurred with its location, local history and the local projects of an organization.

\section{An extraordinary slum neighbourhood in between urban-rural life in İstanbul: Küçük Armutlu}

Küçük Armutlu is a unique neighbourhood as it spends an effort and achieves to preserve rural traditions in an urban setting through its relation to green, social organization and social interaction. It has achieved to maintain an Anatolian characteristic in the urban setting of Istanbul in spite of the more than 35 years inhabited here. K. Armutlu is a neighbourhood where it ties to urban life strongly with its location, surrounded by TEM highway, and central business districts Levent and Maslak, located in the border of Sariyer Municipality. 


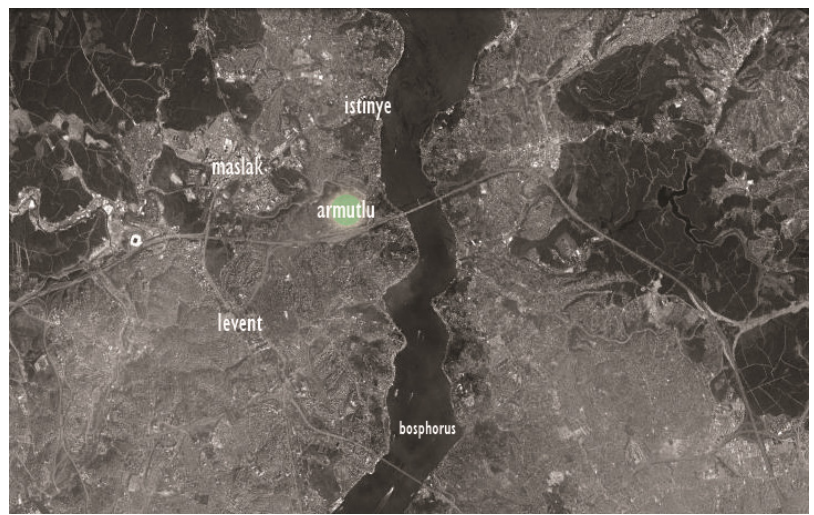

Figure 1: Location.

K. Armutlu neighbourhood settled in the early 1980s just like many others in the city of Istanbul as simple one floored slum houses. This neighbourhood had a different development history from the other settlements as the rest of the slum houses had turned into apartment blocks while this place kept its original and rural character. The neighbourhood has been established through the help of a revolutionist organization who have shared the parcels of the neighbourhood among a group of urban poor family. The neighbourhood has struggled including a deadly battle- against demolition managed by the government since the day it was established. Up to 1989 , the story of K. Armutlu was not different from similar settlements in Istanbul until the big demolitions in the neighbourhood and the entry of a revolutionist organization affected the way the neighbourhood was politically and structurally developed. This organization played a leading role in the collective organization of construction sites in $\mathrm{K}$. Armutlu where there was a vast area of public land [4]. The most determining effect on this preserving history is its relations with the revolutionist organization.

K. Armutlu differs from other neighbourhoods by means of organization. "People's Committee" (Halk Meclisi) initiated by the residents and rules the neighbourhood, is one of the reasons why this neighbourhood has survived attempts of demolition for so long. The neighbourhood is directed through the decisions taken by "People's Committee" It makes sure that the physical appearance of the settlement does not change or change through minor alterations. For instance, no additional stories to one or two story buildings are allowed and this rule is controlled regularly. The control mechanism established through the appearance of the neighbourhood is what makes sure it keeps its rural character in an urban setting. The prevention established in the vertical direction also applies in the horizontal. The houses with a small garden are not allowed to enlarge so that it shrinks the garden space unless a necessary vital reason exists. These are very small gardens (5-10 $\mathrm{m}^{2}$ approx.) that grow vegetables or fruit trees. 


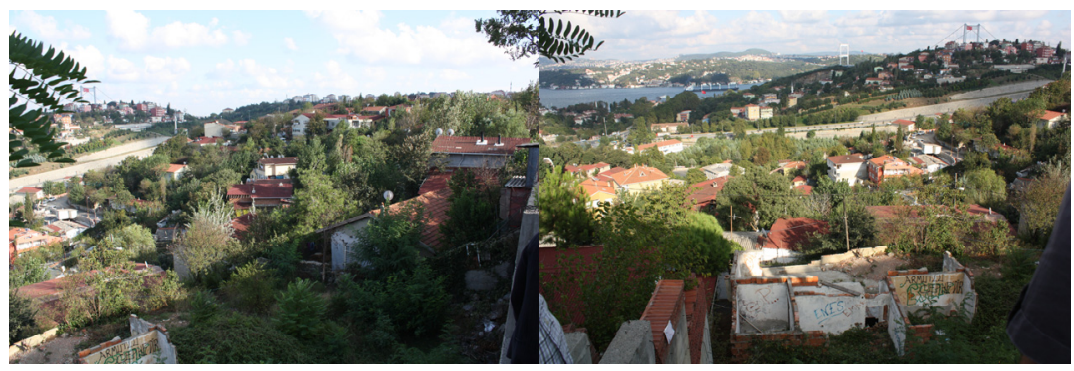

Figure 2: Neighbourhood.

Small residential gardens are important for their role in establishing a rural character for the neighbourhood. This is a point that should not be undermined since it's not a feature that appears frequently in slum neighbourhoods in Istanbul. Establishing a rural character through gardens is important for ecologic sustainability and for allowing the residents to be in touch with the green through the day out. The focus of this paper however, is not these small gardens but the Community Garden Project, which plays a role in giving the neighbourhood its rural character. The Community Garden has a significant role in the neighbourhood through the way it is established, managed, and how it distributes the harvest. Contrary to small residential gardens, the Community Garden is prepared for planting and planted through a common effort. The Community Garden is not operated as a hobby garden and this is how it distinguishes among other types of urban gardens in Istanbul such as copse (koruluk), public garden (mahalle bahçesi) and vegetable garden (bostan) from the Byzantium times. There are also other gardens in Istanbul that is initiated and run by various civil groups in order to establish a social interaction in the neighbourhood. The Community Garden differs from those ones just mentioned through how it is run by the residents of the neighbourhood rather than civil groups and how it gives back to the neighbourhood just as the Community Market or Community Bakery does. Contrary to the situation that of in the Community Garden in K. Armutlu, Lyson [5] states that "The urban agriculture movement in particular has reached a key moment in which activists are avidly promoting the growth of local food production in cities around the country" where the whole garden project is structured through a bourgeois sensitivity rather than local initiation and effort. The fact that the Community Garden is not an urban event but it is a rural practice; a routine part of the everyday life in $\mathrm{K}$. Armutlu is what makes it unique.

Stocker and Barnett [6] and Holland [7] identify community gardens as providing a model for promoting sustainable urban living. However this case in $\mathrm{K}$. Armutlu does not quite fit in this description since it presents a rural way of living rather than an urban way of living although it is located in an urban location. K. Armutlu stands in a cross-section where it's neither an urban garden since it's not executed as leisure nor a rural garden since their economy doesn't depend on agricultural practices. Stocker and Barnett [6] continue with a peaceful statement arguing that "such community-based sustainability projects 
provide physical expressions to local governments of where community groups are 'coming from': what the community group want in their lives; what they understand by 'sustainability'; what skills they have; and how they wish to represent their culture(s) in relation to the environment". Addition to those peaceful statements, one of the reasons why the neighbourhood has initiated the Community Garden in K. Armutlu is a stance against the government.

Left-wing politic traditions habit to oppose, organize, work in collaboration, and stand against power affects emergence of fast and solid reactions [8]. Oppositional saying in Turkey tends to develop a discourse through environment and green. Gezi Park protests in 2013, is a turning point for the citizens to raise their voice for their rights to the city as well as their personal rights in everyday life. Since the movement, it has been a tactical move to reclaim the green as a means of struggle just as it has been adopted in K. Armutlu. The government seeks to create value from urban public land and aims to reshape the urban space. The Community Garden project can be propounded as a tactical response to governmental agenda.

Holland [7] argues, community gardens may appear in different forms and may serve different needs, many community gardens have developed as a response to such issues as social exclusion and poverty, environmental degradation and a lack of local facilities for play and recreation. Milbourne [9] focuses on community gardening in disadvantaged urban spaces also provides a different perspective on the relationship between creativity and regeneration in the city. Community gardening in places of poverty is producing different, but equally important, vernacular forms of creativity that are contributing to the reinvention and, in some cases, the regeneration of these places. He highlights how community gardening projects are able to transform the social and cultural, as well as physical, attributes of space and, in so doing, remake place and create new forms of sociality and conviviality [9]. As Crouch notes the garden has been an informing metaphor for geographical thought for sometime and as an affective material object and gardening as a process in the figuring and refiguring of space. The significance of the garden in world religions is pervasive, demonstrating its power to define space [10]. The Community Garden in K. Armutlu can be alleged as a hidden tactical response that establishes a solidarity stance.

In this section we attempted to present how the Community Garden in K. Armutlu both comply and differ from the generalizations that have been made so far about community gardens. The next section intends to give further insight about the garden so that its role as a tactical act is better understood.

\section{Küçük Armutlu Community Garden}

Küçük Armutlu Community Garden was established in 2014. In its second year it has spread to Çayan and Gazi districts in Istanbul and Hüseyingazi District in Ankara. These districts that the Community Garden has spread to are all urban poor neighbourhoods that are ruled by left organizations. Here we see that the 
garden project in $\mathrm{K}$. Armutlu is taken as a model and started spreading in other neighbourhoods as well.

The Community Garden in K. Armutlu refuses to use seeds from multinational seed industries. According to seed law constituted in 2006 [11], they are not allowed to use local seeds either. Therefore, they place call over Anatolia to participate in establishing a seed bank. Most commonly they plant vegetable. The aim of this garden is not harvest but establishing a stronger solidarity stance in the neighbourhood. Annual events in the garden take place in the form of a festival that is, seeding and harvest festival. Harvest festival in particular is announced across the country and the content of the festival consists of songs, folk dance and plays in addition to harvesting.

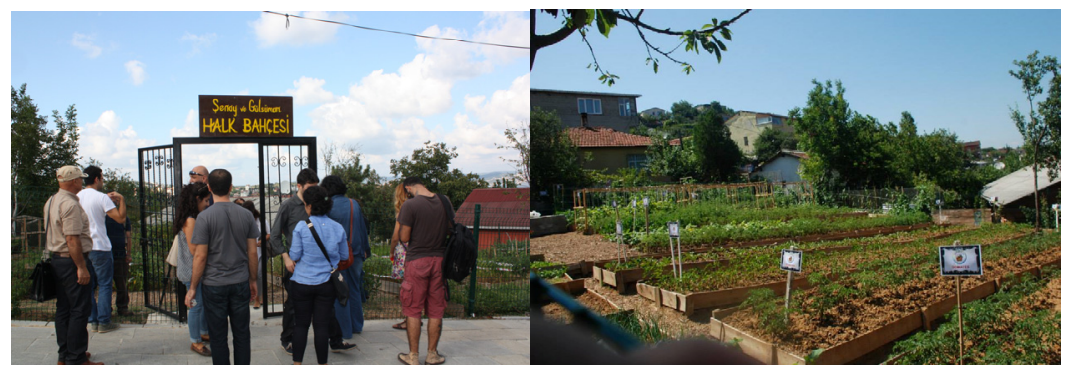

Figure 3: Community Garden.

Community Garden in K. Armutlu is run through an integration of community science, innovative technologies and horticultural techniques that consists of traditional sustainability techniques inherited from Anatolian rural which are not one but several. This integration and variety of techniques stemming from experience gives rise to social interaction through conflicts, discussions and dialogues. In the interviews conducted with agricultural engineers in People's Engineers and Architects organization, they state that they have things to learn from the community; and that execution is an amalgam of engineering knowledge and traditional agricultural heuristics. Every person working in the garden has a say in how to proceed and what not to do. The interactive nature of the garden is a representative of the neighbourhood culture and that the garden is not run in a positive but in a community science approach.

The garden is nourished by the volunteered residents of the neighbourhood and the unofficial organization, People's Engineers and Architects (PEA). PEA still has a leading role in the garden due to its recent establishment. The number of people working in the garden and visiting the seeding fest has showed an insignificant increase this year. One of the reasons for not marking a significant increase in participants is related to this neighbourhood being labelled as an urban transformation site. The residents refuse to move from their homes and they stand in solidarity against the government. Therefore, the government aims to weaken the solidarity in the neighbourhood through applying arbitrary detention to those people who take place in PEA projects and establish an uncanny feeling in the neighbourhood yielding people to hesitate to take part in 
the PEA projects. However, congruent official pressure does not bring the garden project to a halt.

\section{Interviews}

In depth interviews with members of its coordinating group, discussions with residents, participant observations at the events in the festivals are conducted. Drawing on observations from this work, this section discusses the roots of the project, the spaces within which it operates and cultures and creativities bound up with its activities in urban-rural context. Questions regarding their experience of the Community Garden and their past rural experience were asked. The responses are evaluated under creation of community place and opportunity for social cultural interaction through which the garden becomes a tool of struggle.

Opportunity for social cultural interaction: The Community Garden acts as a piazza/courtyard/public square where a social network emerges through a community place experience. This puts forth the issue of establishment of sociocultural sustainability rather than an ecologic sustainability. This effect can be understood through how the neighbourhood had been established with a solidarity stance and supported with the ties to an organization. It represents the sustainability of socio-cultural interaction through a variety of projects and the Community Garden is one of these. Lyson [5] classifies a similar case as "urban agriculture" but observes similar effects:

"...they conflated the creation of community through urban food growing with inclusivity. Fostering trust, increasing awareness, and connecting people with each other and the land were all espoused as benefits of the creation of community through urban agriculture.... Many respondents expressed the idea of building and sustaining a sense of community through urban agriculture as a central motive for participation."

One of the residents who lives in one of the houses that the harvest is distributed among but does not actively work in the garden (age around 58, female) states that she is too old to work in the garden but she serves tea to those working there and warns them if she sees that they are doing something wrong. She says that they used to farm in her hometown but she could not do it in the city. She says that her garden is too small to plant but she still feels like in her hometown whenever she passes by the Community Garden and sees those eggplants grow.

One of the residents who is also a member of People's Committee (age 65, male) tells the story on how the garden was established: there was a house on this parcel and its residents started selling drugs. They were warned many times, they were caught red-handed selling drugs to young people and denounced in the neighbourhood. But they did not listen. In the end, People's Committee decided to expel them from the neighbourhood and demolish the house. After the demolition, the remains of the house were left there intentionally as a lesson. Then we turned it into a garden that would serve the whole neighbourhood. The same story repeats for another house. Its remains have not been removed yet but 
it will too turn into a community garden after a while. People's Committee, consisting of a group of members who live in this neighbourhood, looks out for the rules set by the habitants in this neighbourhood; they warn any one not complying with the rules then, they denounce them if they persist they demolish the house. In literature, "community gardening projects largely occupy the mundane or everyday spaces that have been neglected or abandoned by the local state or private landlords - what Whitehead, drawing on the work of Lefebvre, has referred to as "remaindered" spaces. However the abandonment of these spaces does not mean that they represent empty spaces as they are often awarded a significant meaning by local residents - as sites of neglect, waste, crime and anti-social behaviour and as powerful symbols of urban disadvantage". Similar to the case in K. Armutlu, "community gardening projects have sought to alter the meanings of these spaces, with the physical transformation of land also producing new spaces of identity, sociality and empowerment. In addition, Schmeizkopf states that "it is claimed that community gardening activities are producing new hybrid or "third spaces" that intersect public and private worlds and which are "part of the public domain and are the sites of many functions conventionally equated with the private sphere" [12].

A 25 year old female agriculture engineer, a member of PEA states that what they wanted to do is to show the residents that they have power to change things. What is possible? At first, they did not believe that they could grow their own food. First, we started planting then they got involved. After the first harvest in this garden, they started to grow food in their own gardens that they did not use before. Similar to Lyson [5], PEA member states that they showed the residents of the neighbourhood that they are not without alternative. "The urban agriculture... premised on promoting local, environmentally sustainable, healthy, and socially inclusive alternatives to the industrialized food system."

\section{Conclusion}

Gezi Park protests in 2013, is a turning point for the citizens to raise their voice for their rights to the city as well as their personal rights in everyday life. Since the movement, it has been a tactical move to reclaim the green as a means of struggle just as it has been adopted in Küçük Armutlu. The government seeks to create value from urban public land and aims to reshape the urban space there. The Community Garden project is a tactical response to this governmental agenda. It seeks to establish a stronger solidarity stance in the neighbourhood through creating social interaction and a community place while maintaining the Community Garden.

\section{References}

[1] Atkinson, A., Readjusting to Reality. An Urban and Peri-Urban Agriculture to Ease the Downward Passage, City, Vol.17, no. 1, pp. 85-96, 2013.

[2] Şengül, T., Kentsel Çelişki ve Siyaset, İmge Kitabevi, Ankara, 2009. 
[3] Tacoli, S., Rural-Urban Interactions: A Guide to the Literature, Environment and Urbanization, Vol. 10, No. 1, April, 1998.

[4] Gönül, E., Cörüt, I., From Almus to Küçükarmutlu: An Ethnographic Study of the Rural and Sub-Urban Space in Relation to State and Market Intrusions, Journal of Historical Studies, (5), pp. 33-67, 2007.

[5] Lyson, H.C.; Social Structural Location and Vocabularies of Participation: Fostering a Collective Identity in Urban Agriculture Activism. Rural Sociology, 79 (3), pp. 310-335, 2014.

[6] Stocker, L. \& Barnett, K., The Significance And Praxis of CommunityBased Sustainability Projects: Community Gardens in Western Australia, Local Environment: The International Journal of Justice and Sustainability, 3:2, pp. 179-189, 1998.

[7] Holland, L., Diversity and connections in community gardens: a contribution to local sustainability, Local Environment: The International Journal of Justice and Sustainability, 9:3, pp. 285-305, 2004.

[8] Yücel, H., Aksümer, G. Kentsel Dönüşüme Karşi Kent hakki Mücadelesi: Kazim Karabekir Mahallesi'nde Mekânsal Kimlik Ve Dayanişma Örüntüleri, Eğitim, Bilim, Toplum, 9(36), pp. 117-139, 2011.

[9] P. Milbourne, "Growing places: Community gardening, ordinary creatives and place-based regeneration in a northern English city" in Eds.Tim Edensor, Deborah Leslie, Steve Millington and Norma Rantisi "Spaces of Vernacular Creativity: Rethinking the cultural economy" Routledge, London, pp. 141-154, 2010.

[10] Crouch, D., "Gardens and Gardening” in Ed. Rob Kitchin \& Nigel Thrift "International Encyclopaedia of Human Geography" Vol. 4, pp. 289-293, Elsevier, Oxford, 2009.

[11] http://www.resmigazete.gov.tr/eskiler/2006/11/20061108-1.htm

[12] P. Milbourne, Everyday (in)justices and ordinary environmentalisms: community gardening in disadvantaged urban neighbourhoods, Local Environment Vol. 17, No. 9, October 2012, 943-957. 2012. 